\title{
BIOTECHNOLOGICAL APPLICATIONS OF LACCASES IN THE TEXTILE INDUSTRY
}

Kiro D. Mojsov*

Faculty of Technology, University of Štip, Republic of Macedonia

Owing to the specific nature, enzymes have become an important class of biochemicals in textile processing. The use of enzymes in the textile processing is rapidly gaining globally recognition because of their non-toxic and eco-friendly characteristics to reduce pollution in the textile production. The search for efficient technologies has increased the interest in the use of enzymes to substitute conventional chemical textile processes by environment-friendly and economically attractive bioprocesses. Furthermore, the use of enzymes results in reduced process times, energy and water savings, the improved product quality and the potential process integration. Among the different existing oxidant enzymes, laccases have been the subject of the intensive research in the last decades. Laccases are Oxidoreductase class of enzymes (benzenediol: EC 1.10.3.2). Laccases are generally active at $\mathrm{pH} 3-5$ and in the optimal temperature range of $30-50^{\circ} \mathrm{C}$. They oxidize by using molecular oxygen as an electron acceptor from the substrate. Laccases are used to bleach textiles, can be used for textile dyeing/finishing, and many other industrial, environmental uses. This review mainly focuses on the use of laccases as an alternate technology to the conventional methods.
(REVIEW PAPER) UDC 677.027.26:577.152.1

Keywords: enzymes, laccases, bleaching, decolouration, denim.

\section{Introduction}

Enzymes are natural protein molecules that act as highly efficient specialized catalysts in biochemical reactions, that is, they help a chemical reaction take place quickly and efficiently. Enzymes not only work efficiently and rapidly but they are also biodegradable. Commercial sources of enzymes are obtained from three primary sources: animal tissue, plants and microbes. Enzyme manufacturers produce enzymes in accordance with all applicable governmental regulations. Most of the industrial enzymes are produced by a relatively few microbial hosts like Aspergillus and Trichoderma fungi, Streptomyces fungi imperfecti and Bacillus bacteria. Yeasts are not good produces of extracellular enzymes and are rarely used for this purpose. There are large numbers of microorganisms which produce a variety of enzymes [1]. Microorganisms producing enzymes of textile important are listed in Table 1.
Table 1. Microorganisms producing enzymes of textile important

\begin{tabular}{ll}
\hline Microorganisms & Enzymes \\
\hline 1. Bacteria & \\
Bacillus subtilis & Amylase \\
B. coagulans & a-amylase \\
B. licheniformis & a-amylase, protease \\
S. lavendulae & Laccase \\
S. cyaneus & Laccase \\
Marinomonas mediterranea & Laccase \\
2. Fungi & \\
Aspergillus & a-amylase \\
A. niger & Amylases, protease, \\
& pectinase, glucose oxidase \\
A. oryzae & Amylases, lipase, protease \\
Aspergillus & Catalase \\
Candela lipolytica & Lipase \\
Rhizopus & Lipase \\
Aspergillus & Lipase \\
Trichoderma reesei & Cellulase \\
T. viride & Cellulase \\
Trichoderma & Cellulase \\
Trameters & Cellulase \\
Hirsuta & Cellulase \\
P. notatum & Glucose oxidase \\
Aspergillus sp. & Pectinase, lipase \\
Monilinia & Pectinase \\
Fructigena & Pectinase \\
Aspergillus & Protease \\
Phlebia radiate & Laccase \\
Pleurotus ostreatus & Laccase \\
Trametes versicolour & Laccase \\
Trichoderma atroviride & Laccase \\
Trichoderma harzianum & Laccase \\
Trichoderma longibrachiatum & Laccase \\
\hline & \\
&
\end{tabular}

\footnotetext{
*Author address: Kiro D. Mojsov, University of Štip, Faculty of Technology, Krste Misirkov bb, Štip, Republic of Macedonia

E-mail: kiro.mojsov@ugd.edu.mk

The manuscript received: Oktober, 31, 2013.

Paper accepted: February, 10, 2014.
} 
Due to the constantly increasing level of pollutants, the governments of many countries impose stricter limitations on the release of pollutants. The textile industry, particularly the chemical processing sector, always has a major share in the global pollution. In the conventional textile wet processing, the grey fabric has to undergo a series of chemical treatments before it turns into a finished fabric. The chemicals used are quite toxic. The generation of pollution is significantly high in the preparatory and dyeing operations compared to the post dyeing operations. Enzymes play a key role in such alternative processes. Enzymes can often replace chemicals or processes that present safety or environmental issues. Amylases were the first enzymes applied in textile processing to remove starch-based sizes from fabrics after weaving. Later proteases were introduced into detergent formulations to remove organic protein- based stains from textile garments and cellulases to remove fibrillation in multiple washes. Cellulases, proteases, amylases, catalases, pectinases, peroxidases and laccases are the enzymes that can replace aggressive chemicals and classical technological procedures [2]. The progress of industrial biotechnology in the last twenty years, especially in molecular biology, protein engineering and fermentation technology, has enhanced the development of new uses of enzymes in the textile industry.

The search for efficient and oxidation technologies has increased the interest in the use of enzymes to replace the conventional technological methods. Laccases (benzenediol: oxygen oxidoreductases, EC 1.10.3.2) have been the subject of the intensive research in the last decades. Most laccases are extracellular enzymes, making the purification procedures very easy and easily applicable in biotechnological processes. Laccases are copper-containing oxidase enzymes that are found in many plants, fungi, and microorganisms. Laccases are especially abundant in white-rot fungi, which are the only micro-organisms able to degrade the whole wood components and have attracted increasing scientific attention. The major enzymes associated with the lignin degradation are laccase, lignin peroxidase and manganese peroxidase. These enzymes can be used for textile dyeing/ finishing and many other industrial, environmental uses. An important feature of fungal laccases is a covalently linked carbohydrate moiety (10-45\%), which may contribute to the high stability of the enzyme [3]. The first commercial use of laccases in the textile industry was in the denimwashing process. The use of laccases in the textile industry is growing very fast, since besides to decolourise textile effluents, laccases are used to bleach textiles [4] and synthetize dyes [5].

In textile dyeing, large amounts of dyestuffs are used. The discharge effluent has high COD (chemical oxygen demand), BOD (biological oxygen demand), suspended solids and intense colour due to the extensive use of dyes. This type of water must be treated before discharging it into the environment. Textile dyestuffs with different structures are decolourized at different rates.

\section{Applications of laccase in the textile industry}

Laccase is important because it oxidizes both toxic and nontoxic substrates. It is utilized in textile industry, food industry, wood processing industry, pharmaceutical industry, and chemical industry. Laccase is used in commercial textile applications to improve the whiteness in conventional bleaching of cotton and the biostoning process. Potential benefits of the application include chemicals, energy, and water saving. Approximately 10,000 different dyes (800,000 tons per year) are produced annually worldwide and used extensively in the dyeing and printing industries, and at least $10 \%$ of the used dyestuff enters the environment through wastes [6]. Physical and chemical methods may be used for the removal of color from wastewater, but these methods are quite expensive and have operational problems. The chemical structure of dyes provides a resistance to fading when exposed to light, water, and other chemicals. Laccase catalyzed textile dye bleaching may be useful in finishing the dyed cotton fabric. Laccase degrades the dye, that is why laccase-based processes have been developed which include synthetic dyes and are being used in the industry nowadays $[7,8]$. Laccase-based hair dyes are less irritant and easier to handle than conventional hair dyes because laccases replace $\mathrm{H}_{2} \mathrm{O}_{2}$ in the dye formulation [9]. White rot fungi are the most efficient ligninolytic organisms capable of degrading various types of dyes such as azo, heterocyclic, reactive, and polymeric dyes [10]. Laccase are also used in increasing the dechlorination activity due to which the dissolved oxygen concentration is reduced [11].

Denim finishing in the denim industry, the removal of indigos is an essential step to give the fabric its abrasion effect. Laccase was shown to be able to degrade indigos and that, without mediator, Trametes vesicolor laccase was more effective in denim finishing $[12,13]$.

Laccase enzyme is used to enhance the fixation of the dye on wool. This coloring method presents the economical advantage of reducing the amount of the dye used when deeper colors are to be obtained [14]. Laccase is also used to decolorize wool from azo-dyes [15].

Laccase enzyme could be used for the roving treatment to improve the yarn regularity [16]. The advantage of the use of laccase in rove scouring is that the process is performed under mild reaction conditions thus resulting in an ecologically-friendly process.

The conventional treatment of wool against shrinking is chlorination which has a negative impact on the environment. Therefore, the enzymes were tried to replace this polluting process. This process was replaced by the proteinases treatment due to their high specificity and a much lower environmental impact. Also, it was found that the laccase treatment of the wool fiber, together with a mediator, prevents the fabric from shrinking [17].

The laccase enzyme was efficacious to form red azo dyes by the oxidative coupling of 3-methyl-2-benzothiazolinone hydrazine and phenols [18]. The synthesis of 
new colorants by laccase are currently developed from phenolic and polyphenolic compounds [19].

\section{Conclusion}

Laccases are promising enzymes to replace the conventional chemical processes of the textile industry. Laccases are produced by wide variety of plants, fungi, bacteria and insects. Laccases have become important industrial enzymes that can be used for a number of diverse applications. They have many industrial applications because of their innate ability of oxidation of a broad range of phenolic and non-phenolic compounds. Laccases have the property to detoxify a range of pollutants, which have made them to be useful in many industries including textile industries. However, one of the limitations for the large-scale application of laccase is the lack of capacity to produce large volumes and affordable cost. The use of inexpensive sources for the laccase production is being explored in recent times. Besides solid wastes, wastewater from the food processing industry is particularly promising for that. Therefore, it is not surprising that this enzyme has been studied intensively and yet remains a topic of the intense research today.

\section{References}

[1] P.D. Boyer, The enzymes, 3rd ed., Academic Press, Inc., New York, 1971, Vol.5.

[2] Cavaco-Paulo, G.M. Gübitz, Textile processing with enzymex, Woodhead Publishing, Cambridge, 2003, p. 240.

[3] N. Durán, J.N. Jenkis, W.L. Parrot, Applications of laccases and tyrosinases(phenoloxidases) immobilized on different supports: a review, Enzyme Microb. Tech., 31 (2002) 907 - 931.

[4] S. Vinod, Enzymatic decolourisation of denims: A novel approach, Colourage, 48 (2001) 25 - 26.

[5] L. Setti, S. Giuliani, G. Spinozzi, P.G. Pifferi, Laccase catalyzed-oxidative coupling of 3-methyl 2-benzothiazolinone hydrazine and methoxyphenols, Enzyme Microb. Tech., 25 (1999) 285 - 289.

[6] G. Palmieri, G. Cennamo, G. Sannia, Remazol Briliant Blue $\mathrm{R}$ decolourisation by the fungus Pleurotus ostreatus and its oxidative enzymatic system, Enzyme and Microbial Tech., 36 (2005) 17 - 24.

[7] A. Dominguez, S.R. Couto, M.A. Sanroman, Dye decolorization by Trametes hirsuta immobilized into alginate beads, World Journal of Microbiology and Biotechnology, 21 (2005) 405 - 409.

[8] H. Hou, J. Zhou, J. Wang, C. Du, B. Jan, Enhancement of laccase production by Pleurotus ostreatus and its use for the decolorization of anthraquinone dye, Process Biochemistry, 39(11) (2004) 1415 - 1419.

[9] M.S. Roriz, J.F. Osma, J.A. Teixeira, S.R. Couto, Application of response surface methodological approach to optimize Reactive Black 5 decolouration by crude laccase from Trametes pubescens, Journal of Hazardous Materials, 169 (1-3) (2009) 691 - 696.

[10] C. Novotny, P. Erbanova, T. Cajthaml, N. Rothschild, C. Dosoretz, V. Sasek, Irpex lacteus, a white rot fungus applicable to water and soil bioremediation, Appl. Microbiol. And Biotech., 54 (2000) 850 - 853.

[11] A. Unal, N. Kolankaya, Dechlorination of bleached kraft pulp by laccase enzyme produced from some white-rot fungi, Turkish Electronic Journal of Biotechnology, 25 (2001) 67 - 72.

[12] R. Campos, A. Kandelbauer, K.H. Robra, A. CavacoPaulo, G.M. Gübitz, Indigo degradation with purified laccases from Trametes hirsute and Sclerotium rolfsii, J. Biotechnol., 89 (2001) 131 - 139.

[13] N.K. Pazarlioglu, M. Sariisik, A. Telefoncu, Laccase: production by Trametes versicolor and application to denim washing, Process Biochem., 40 (2005) 1673 - 1678.

[14] A. Zille, Laccase reactions for textile applications, PhD Thesis, Universidade do Minho, Portugal, 1996.

[15] S. Ryan, W. Schnitzhofer, T. Tzanov, A. Cavaco-Paulo, G.M. Gübitz, An acid-stable laccase from Sclerotium rolfsii with potential for wool dye decolourization, Enzyme and Microbial Technology, 33 (2003) 766-774.

[16] H.S.S. Sharma, L. Whiteside, K. Kernaghan, Enzymatic treatment of flax fibre at the roving stage for production of wet-spun yarn, Enzyme Microb. Tech., 37 (2005) 386 $-394$.

[17] R. Lantto, C. Schänberg, J. Buchert, Effects of laccasemediator combination on wool, Textile Res. J., 74 (2004) $713-717$

[18] L. Setti, S. Giuliani, G. Spinozzi, P.G. Pifferi, Laccase catalyzed-oxidative coupling of 3-methyl 2-benzothiazolinone hydrazine and methoxyphenols, Enzyme Microb. Tech., 25 (1999) 285 - 289.

[19] R. Mustafa, L. Muniglia, B. Rovel, M. Girardin, Phenolic colorants obtained by enzymatic synthesis using a fungal laccase in a hydro-organic biphasic system, Food Res. Int., 38 (2005) 995-1000. 
Izvod

\section{BIOTEHNOLOŠKE PRIMENE LAKAZE U TEKSTILNOJ INDUSTRIJI}

Kiro D. Mojsov

Tehnološko-tehnički fakultet, Univerzitet u Štip, Republika Makedonija

Zbog specifične prirode, enzimi su postali važna klasa bioloških jedinjenja u obradi tekstila. Upotreba enzima u obradi tekstila dobija globalno priznanje zbog svojih netoksičnih i ekoloških karakteristika za smanjenje zagađenja u tekstilnoj proizvodnji. Potraga za efikasnijim tehnologijama je povećala interesovanje za korišćenje enzima koji će zameniti konvencionalne hemijske procese ekološkim i ekonomski atraktivnim bioprocesima. Osim toga, korišćenje enzima dovodi do smanjenja vremena obrade, do uštede energije i vode, do poboljšanja kvaliteta proizvoda i potencijalnog procesa integracije. Među različitim postojećim oksidativnim enzimima, lakaze su predmet intenzivnih istraživanja u poslednjih nekoliko decenija. Lakaze spadaju u klasu enzima Oksidoreduktaze (benzendiol: EC 1.10.3.2). Lakaze su uglavnom aktivne pri pH 3 - 5 i na optimalnoj temperaturi od $30-50{ }^{\circ} \mathrm{C}$. One vrše oksidaciju koristeći molekularni kiseonik kao acceptor elektrona iz supstrata. Lakaze se koriste za izbeljivanje tekstila, mogu da se koriste za bojenje tekstila/doradu i mnoge druge industrijske, ekološke upotrebe. Ovaj pregled se uglavnom fokusira na korišćenje lakaza u tehnologije koje su alternativa konvencionalnim metodama.
(PREGLEDNI RAD)

UDK 677.027.26:577.152.1

Ključne reči: enzimi, lakazi, belenje, dekoloracija, teksas 